1994

\title{
Three Visions of Managed Competition, $1920-1950$
}

Rudolph J.R. Peritz

New York Law School

Follow this and additional works at: https://digitalcommons.nyls.edu/fac_articles_chapters

Part of the Antitrust and Trade Regulation Commons

\section{Recommended Citation}

Antitrust Bulletin, Vol. 39, Issue 1 (Spring 1994), pp. 273-288

This Article is brought to you for free and open access by the Faculty Scholarship at DigitalCommons@NYLS. It has been accepted for inclusion in Articles \& Chapters by an authorized administrator of DigitalCommons@NYLS. 


\section{Three visions of managed competition, 1920-1950}

BY RUDOLPH J. R. PERITZ*

I. Introduction: free competition

The phrase "managed competition" has become a commonplace since the last presidential campaign, particularly with regard to health care reform. It seems, as well, to be the guiding principle behind the Clinton administration's approach to trade policy. Because the FTC and Department of Justice are still in transition, it is too early to tell how the phrase, the principle, or both, will migrate into-antitrust policy.

But it is not too early, I believe, to look into the history of managed competition, to develop a sense of what it has meant in practical, programmatic terms. It is not a new policy approach. On the contrary, the idea of managed competition is as old as its counterpart-"free competition."

$I$ begin this article by asking a few questions about free competition as a way of developing a working model of managed competition. These questions have emerged from my historical

* Professor of Law, New York Law School.

- 1994 by Federal Legal Publications, Inc. 
research into American competition policy since the Sherman Act debates. With my working model as a framework, I present the three dominant visions of managed competition that inspired Congress and enforcement agencies in the United States between 1920 and 1950. (In a departure from most studies of antitrust and competition policy, this article will ignore Court doctrine.)

Free competition. From what tyranny do we want to free competition? From the political power of government? Or from the economic power of dominant firms and cartels? If, for example, efficiency is our goal and if we believe that competition free of government management produces and distributes capital, goods, and services most efficiently, then even predatory pricing or pricefixing cartels do not justify government intervention. If, however, we believe that efficiency is threatened by dominant firms or cartels, then political oversight is mandated. And for those of us who distrust all discretionary power, whether political or economic, can we formulate policy that limits both public and private management of competition?

The history of competition policy in America can be understood as a series of approaches to resolve this tension embodied in the idea of "free competition." None of these approaches has disappeared into history. Each of them, at least traces of each, remain part of today's rhetoric of free competition. ${ }^{1}$

When free competition has meant freedom from government supervision, when it has meant laissez-faire, commercial markets have sometimes been competitive but more often, privately managed. Privately managed competition is the result of market power

1 For expanded discussions, see Rudolph J.R. Peritz, AMERICAN CoMpetition Policy Since 1888: A Counter-History (forthcoming Oxford University Press) [hereinafter American CoMpetition Policy SiNCE 1888]; Forward: Antitrust as Public Interest Law, in Symposium Observing the Sherman Act Centennial: The Past and Future of Antitrust as Public Interest Law, 35 N.Y.L. Scr. L. Rev. 767 (1990); A CounterHistory of Antitrust Law, 1984 Duke L.J. 263; The "Rule of Reason" in Antitrust Law: Property Logic in Restraint of Competition, 40 Hastings L.J. 285 (1989). 
over rivals or bargaining power over trading partners. That is, management of either horizontal or vertical competition. Management power can rest in the hands of one dominant firm or in a cartel. Thus, "free competition" has often produced competition managed by market participants with some sort of economic power. The classical arguments for this form of free competition have descended from liberty of contract, from the freedom to exercise one's property rights without government interference. Neoclassical arguments have derived from the belief that unfettered competition is more "efficient," in some sense of the term. ${ }^{2}$

When free competition has meant freedom from dominant firms or cartels, when it has meant rivalry amongst numerous competitors, commercial markets have sometimes been competitive and often, publicly managed. Publicly managed competition has meant active government enforcement to limit the exercise of private economic power, either vertical or horizontal. It has taken many forms, including antitrust rules for competition, tax incentives, and trade policy. The classical arguments for this form of free competition have stemmed from a deep distrust of economic power, a strong preference for small business, from the ideology of Jeffersonian entrepreneurialism. Neoclassical arguments have derived from the familiar economic model of perfect competition.

2 A good example of the difference between classical and neoclassical arguments for free competition can be seen in two contrasting formulations of the "rule of reason." In the Standard Oil opinion written by Chief Justice Edward D. White, 221 U.S. 1 (1911), the "rule of reason" meant the public policy of competition was best served by protecting private rights of contract: The "rule of reason" was intended "to prevent [the Sherman Act] from destroying all liberty of contract and all substantial right to trade, and thus causing the act to be at war with itself by annihilating the fundamental right of freedom of contract." Justice Louis D. Brandeis" restatement of the "rule of reason" in the Chicago Board decision, 246 U.S. 231 (1918), turned this deductive analysis on its head, determining inductively the reasonableness of a contract by looking at its public effects: Does the private agreement "regulate[] and thereby promote[] competition or [does it] suppress or even destroy competition?" 
Seen in terms of this preliminary model, free competition and managed competition can be understood as complementary. ${ }^{3}$ Each is the limit of the other. Their dynamic relationship turns on this question: From what tyranny do you want to free competition? This simple question has produced complex policy responses over the last century. The question itself becomes even more difficult when asked of the last 50 years, in the context of postclassical economics-Edward Chamberlain's theories of oligopoly and monopolistic competition, and Joseph Schumpeter's theory of dynamic competition. ${ }^{4}$ But, I believe, the basic question remains the same.

In the body of this article, I present three visions of managed competition and thus, by implication, three correlative views of free competition. I place each vision in its historical and economic context, between 1920 and 1950, and trace the vision through the practical antitrust program that followed. From what tyranny did Congress or the Executive seek to free competition? What were the practical consequences of each program to manage competition?

The first vision has come to be associated with Herbert Hoover and the trade association movement. The second inspired Franklin Roosevelt's early New Deal, especially the National Industrial Recovery Act. The third informed a series of statutes passed later in the New Deal and in the Truman administration.

3 I have described these two views of competition in terms of a conflict between liberty and equality. See sources cited in note 1 supra.

4 Edward Chamberlain, The Theory of Monopolistic Competition (1932); Joseph Schumpeter, Capitalism, Socialism aNd Democracy (1942). Schumpeter was quick to point out that Alfred Marshall, the original price theorist, recognized the common occurrence of monopoly power and thus, anticipated the work of Chamberlain. For his earlier and more circumspect description of economic development as "revolutionary" or discontinuous change by entrepreneurs, see JoSEPH A. SCHUMPETER, THE THEORY OF ECONOMIC DEVELOPMENT (1 German language ed. 1911) (R. Opie trans., 1934), particularly his discussion of the "fundamental phenomenon of economic development" at 57-94. 
II. First vision: Herbert Hoover and trade associationalism, $1920-1932^{5}$

A nationwide trade association movement began in the years immediately preceding the Standard Oil decision (1911). By the 1920 s, the era of trade associations was in full bloom. The movement reflected the recent experience of triumph, tempered by established ideology. The recent experience of national mobilization during World War I under Woodrow Wilson's War Industries Board demonstrated the awesome power of industrial cooperation under government management. The flush of success was, however, tempered by the longstanding commitment to individual liberty and a distrust of expansive government, expressed in both the Standard Oil decision's rule of reason and the earlier Lochner (1905) decision's ${ }^{6}$ economic due process jurisprudence, its restraint of state regulation based on constitutional principles of private property and liberty of contract.

Advocates of industrial trade associationalism called for markets administered by contract, by trade associations, to replace "destructive competition" among individual rivals. But an ideological difficulty lay in the inescapable role of government: What sort of political action to manage markets was consistent with freedom of contract, with free competition? To an amazing extent, it was the work of Herbert Hoover, particularly as Secretary of Commerce under Warren G. Harding beginning in 1920, that turned the trade association movement into a full-blown vision of cooperative competition.

Fresh from his success at helping America's European allies begin their recovery efforts after World War I, Herbert Hoover was convinced that "the laws of Scientific Management" could provide the structure for efficient and "socially responsible eco-

5 See Perttz, American Competrtion Policy Since 1888, supra note 1 , at ch. 2 and sources cited therein.

6 Lochner v. New York, 198 U.S. 45 (1905). 
nomic institutions and processes." A wide range of policymakers agreed.

Economist John M. Clark, who would gain notoriety for his development of the influential theory of "workable competition" in the 1940s, wrote in 1923 that trade associations enhanced competition when they promoted information exchange amongst members, thereby avoiding ruinous competition. ${ }^{7}$

Justices Oliver Wendell Holmes, Jr. and Louis Brandeis agreed, Holmes writing in dissent (in American Column \& Lumber (1921)) that the Sherman Act "did not set itself against knowledge-did not aim at a transitory cheapness unprofitable to the community as a whole." 8

Muckrakers such as Ida Tarbell urged a "golden rule," "a live and let live attitude" amongst rivals. Philosopher John Dewey viewed associationalism as a pragmatic exercise in economic democracy. The title page of an enormously popular book, entitled The New Competition (1914) by Arthur Jerome Eddy, a prominent member of Chicago's corporate bar, displays the following phrase, italicized, underlined, within quotation marks, and in 18-point type: "COMPETITION IS WAR AND WAR IS HELL."

Woodrow Wilson's War Industries Board of 1917-1918 encouraged the formation of trade associations to exchange information and stabilize markets. The Department of Commerce published a report estimating that approximately 1000 trade associations were active in 1920. Under Herbert Hoover's tutelage, first as Secretary of Commerce and then as President, by 1933, there were over 10,000 active trade associations.

Hoover organized conferences, encouraged the development of industry standards, and made "house calls" to "sick industries,"

7 John M. Clark, Studies in the Economics of Overhead Costs 432-35 (1923).

8 American Column \& Lumber Co. v. U.S., 257 U.S. 377, 412-14 (1921). 
including the lumber and coal industries. When the Supreme Court held in American Column \& Lumber (1921) that a hardwood trade association violated the antitrust laws, Hoover was outraged, both at the Supreme Court and at the Department of Justice for bringing the suit. Hoover instructed his Department of Commerce to perform the industry organizing activities that trade associations were no longer permitted to do. At the same time, he lobbied successfully to have a new chief of the Antitrust Division who took his view of trade associations. That new chief was Columbia Law School Dean Harlan F. Stone, who, later appointed to the Supreme Court, wrote the Maple Flooring (1925) decision, ${ }^{9}$ which took a more lenient view of trade association activities.

Thus, the trade association movement and Herbert Hoover's support, though remembered as laissez-faire, involved significant government management. Hoover developed a nationwide network, a shadow bureaucracy under the Department of Commerce, to help manage trade association activities. Because there was no formal government involvement-no enabling legislation and no formal system of enforcement-Hoover's efforts did not run afoul of the established ideology of liberty of contract, of free competition. Only in that limited sense can it be thought of as laissezfaire.

Hoover and other advocates of trade associationalism envisioned the movement as propelled by the twin engines of scientific management and industrial statesmanship. Government involvement was seen as limited to the support of scientific management. Industrial statesmanship would manage destructive competition.

That was the vision of trade associationalism. What were the practical consequences?

Perhaps the most significant practical consequence was a radical shift in the individual manager's view of his firm and its relationship to rivals and trading partners. Trade associations were

9 Maple Flooring Manufacturer's Association v. U.S., 268 U.S. 563 (1925). 
formed and managed long before Herbert Hoover entered the scene in 1920. Perhaps the most influential management firm of industrial engineers was Stevenson, Jordan \& Harrison. Despite criminal indictments, consent decrees, and injunctions, the firm maintained its prominence well into the 1940 s. Its management of trade associations was built upon a three-stage price stabilization program. First, they developed a uniform method of accounting, giving rivals the information to compete with restraint. Second, if knowledge of costs was not enough to stabilize markets, they would compile, analyze, and disseminate statistics regarding inventory, shipments, orders, etc. Third, if knowledge of costs and market activity was not enough, the firm developed "the principle of an Equitable Sharing of the available volume of business." The idea was to manage competition, to turn cutthroat into cooperative competition by teaching association members the economic logic of controlling output to raise price levels. ${ }^{10}$

In short, the vision of managed competition held by Herbert Hoover, economist John M. Clark, lawyer Arthur Jerome Eddy, a Supreme Court majority, and many others did not match the practical theory of industry cooperation that led trade association members to appreciate the relationship between limiting output and increasing prices. I do not have the space to discuss here the many reasons for this mismatch. ${ }^{11}$ I conclude by stressing that trade associations taught members an esprit de corps-a sense that

10 For a brief discussion of the influence of industrial engineering consulting firms on the trade association movement, see the wonderful book by George W. Stocking \& MYron W. Watkins, Monopoly and FREE ENTERPRISE 236-43 (1951).

11 I do not discuss here the many reasons for this mismatch. I only mention that the economic frameworks for understanding trade associationalism were a declining classical model of economics and an ascendant neoclassical model, both of which imagined a dichotomous economic world of either competition or monopoly. Trade association activity, so long as it was not monopolistic in the limited senses of the classical and neoclassical models, was seen as competitive. For a detailed treatment, see Peritz, American Competition Policy Since 1988, supra note 1 , at ch. 2 . 
together they could manage competition, that they were competing not with one another but rather with their customers.

\section{Second vision: FDR and the National Industrial Recovery Act, 1933-193512}

Trade associations provided the foundation for Franklin Roosevelt's early vision of managed competition, with a New Deal twist. The National Industrial Recovery Act of 1933 (NIRA) mandated industrial codes of "fair competition" to organize American industry and labor. The statute established both procedural requirements for the drafting process and substantive principles for government approval. Many codes would include explicit price-fixing provisions, as did some trade association bylaws under Harding, Coolidge and Hoover.

The legislative hearings preceding enactment of the NIRA were filled with the utopian vision of a "co-operative effort by those engaged in trade and industry." Frightened by the Depression and its effects on prices, output, and income, everyone seemed to agree that something on the order of Woodrow Wilson's World Industries Board was needed to lead the nation through an economic emergency.

Three principles illuminated this new vision of managed competition, and distinguished it from its predecessor.

First, the process of code drafting would include not only industry members but also consumers and labor. This principle of inclusion stemmed from an appreciation of the two-dimensional nature of competition-not only horizontal but also vertical. This was a simple principle long understood by those involved, including trade association managers, but outside the neoclassical model of competition that informed policymakers.

Second, those participating in code drafting would come to their tasks based on a political norm of equal representation. That is, the large corporations would not dominate the boards. Mem-

12 See id. at ch. 3. 
bership would not be proportional to percentage of industry output. Moreover, the statute, while it suspended the antitrust laws, included a substantive provision prohibiting industrial codes from discriminating against small businesses.

Third, the government would supervise the code drafting process to assure compliance with the statute, and would enforce the codes of fair competition after approval. This principle would not only maintain faimess but also provide the federal oversight that separated the success of Wilson's War Industry Board from the failure of Hoover's trade association movement.

In sum, the legislative history of the NIRA projects an image of managed competition onto an organic body politic. It envisions a cooperative venture with participants whose competitive instincts were tempered by a national esprit de corps, by a sense that a unified political will was needed to avoid economic collapse. Whether because New Dealers agreed with Berle and Means that managers of large corporations were no longer accountable, or with Edward Chamberlain and Joan Robinson that the nature of competition had changed, ${ }^{13}$ or because material conditions in the aftermath of the Versailles Treaty had produced economic hardship worldwide, there was, for a moment in American history, a strong consensus favoring government management of commercial competition to free it from its destructive spiral, from the extremes of destruclive competition and monopoly.

The National Recovery Administration, it was imagined, would convene interest groups-producers, distributors, retailers, consumers, workers-equally represented, supervised by neutral government representatives, informed by economics experts, to negotiate fair terms for economic activity, industry by industry, mimicking the activity of healthy competition.

Whatever we might think of it today, the vision of an organic body politic climbing Jacob's ladder to economic recovery never

13 Adolphe Berle \& Gardner Means, The Modern Corporation and Private Property (1932); Chamberlain, supta note 4; Joan Robinson, The ThEORY OF IMPERFECT COMPETITION (1932). 
really had a chance. The vision did not inform the practice. First of all, the Roosevelt administration simply failed to do its part. There was no bureaucratic infrastructure to support the vision. In consequence, experienced trade association attorneys were drafting codes of fair competition, which were approved by government attorneys barely out of law school. Second, the norm of representational equality never took hold. Instead, industry boards and the NRA itself were dominated by powerful industrialists and trade association representatives. As a result, the code provisions tended to favor their interests. It was no coincidence that most of the thousands of code violation complaints were filed against small businesses. Third, consumer and labor representatives were excluded from the code drafting process. Because workers were organized and consumers were not, labor unrest produced waves of strikes approaching industrial warfare while consumers did not think of themselves as a class and remained unorganized.

By the time the Supreme Court pulled the plug on the NIRA in its ALA Schechter Poultry (1935) decision, ${ }^{14}$ the experiment had already failed. There was little likelihood that Congress would have passed new legislation to continue the agency beyond the 1935 sunset provision. The vision of managed competition did not resemble the practice that followed. The practice that followed was a grotesque parody of Hoover's trade associationalism-on one side enforced by a Kafka-esque government bureaucracy and on the other side, enjoined by most federal judges who had the opportunity.

IV. Third vision: C̀ongress, consumers, and producers, 1935-195015

Hoover's trade associationalism, both in theory and in practice, favored producers. Consumers were, at best, an afterthought. Worker associations, unions, were discouraged, often violently.

\footnotetext{
14 ALA Schechter Poultry Co. v. U.S., 295 U.S. 495 (1935).

15 See Pertiz, American Competition Policy Since 1988, supra note 1 , at ch. 4 and sources cited therein.
} 
Roosevelt's NIRA vision portrayed producers, consumers, and workers as parts of an organic body politic whose economic relationships could be accommodated, negotiated under political supervision. In practice, there was no supervision and no negotiation. Although most antitrust scholars see them as fundamentally different, both visions produced practical programs that favored producers, usually large producers who managed competition either by dominating industries or by organizing trade associations.

While most historians also see New Deal legislation after $A L A$ Schechter Poultry as radically different from the NIRA, most antitrust scholars think of the Robinson-Patman Act and the Miller-Tydings Resale Price Maintenance Act as cut from the same cloth. I disagree with the predominant view amongst antitrust scholars and policymakers that congressional activity after 1935 projects a protectionist vision of managed competition.

Between 1935 and 1950, Congress passed five pieces of legislation that I see in series. Historians and antitrust scholars have not recognized any continuity in them. But I understand them as five statutes linked by a common vision of managed competition.

I will take a passing glance at the five statutes and then conclude my discussion with a few remarks about the statutes and the vision of managed competition they evoke.

The first piece of legislation in my series is the Public Utilities Holding Company Act of $1935 .{ }^{16}$ Though seen today as a securities statute (and indeed, found amongst the securities acts in the United States Code, enforced by the Securities and Exchange Commission (SEC), the Act empowered the SEC to investigate, regulate, and dissolve the huge utility holding companies comprising what was called the "Power Trust." The legislative history is replete with references to the uncontrolled power of minority shareholders at the tip of the pyramidal holding companies, to the "spoliation, mismanagement, and faithless stewardship," and to 
the plunder of individual shareholders and individual utility customers.

In 1936, Congress passed the Robinson-Patman Act, ${ }^{17}$ which strengthened the Clayton Act provision regulating price discrimination. One of the changes eliminated a separate quantity discount defense; the result was that quantity discounts were a defense to price discrimination only if they could be cost-justified-pennyby-penny. Sponsors claimed that large retailers, Sears, Roebuck for example, used their economic power to extort quantity discounts in excess of the cost savings attributable to efficiencies produced by large transactions. In consequence, they argued, local retailers were charged more, subsidizing the large firms. Consumers who dealt with local retailers (most consumers, it was claimed) paid higher prices.

In 1937, the Miller-Tydings Resale Price Maintenance Act essentially delegated to the states the power to make vertical price fixing legal per se. These "fair trade" statutes, passed by fortytwo state legislatures, allowed manufacturers to set the retail prices of their goods. Sponsors argued that "fair trade" was necessary to stop discounters from predatory pricing, from using "loss leaders" to destroy local businesses. Moreover, they invoked an image of individual entrepreneurs as the backbone of America, as the political and economic middle class that held the nation together. ${ }^{18}$

The Wheeler-Lea Act of 1938 amended the Federal Trade Commission Act of 1914, adding to section 5(a) the now familiar

17 Act of June 19, 1936, ch. 592, 49 Stat. 1526, amending Clayton Act $\S 2,15$ U.S.C. $\S \S 13(a)-(f)$ (1976).

18 Act of Aug. 17, 1937, ch. 690, tit. VIII, 50 Stat. 693, amending Sherman Act \& 1 (15 U.S.C. \& 1), repealed by the Consumer Goods Pricing Act of 1975, Pub. L. No. 94-145, § 2, 89 Stat. 801. The statute should be understood in its economic context. Financially powerful firms were already setting resale prices without threat of antitrust prosecution simply by distributing goods on consignment. Under both Dr. Miles Medical Company, 220 U.S. 373 (1911) and General Electric, 272 U.S. 476 (1926), their price fixing was legal per se. The Miller-Tydings Act simply leveled the playing field. 
words "unfair or deceptive acts or practices." As interpreted by the Supreme Court, the original section 5(a) language of "unfair competition" required proof of injury to a competitor. Recommended by the FTC and passed with little debate, the new language was intended to "protect the consumer," without regard to other competitive effects. ${ }^{19}$

Finally, there was the Celler-Kefauver Act of 1950, which amended the Clayton Act section 7 regulation of corporate mergers. Congress expanded the section's coverage of mergers in two significant respects: first, mergers by purchase of assets were brought under the statute; second, not only mergers between competitors, but all mergers were subject to antitrust scrutiny. The postwar concern about corporate size had numerous antecedents, including government lawsuits against large corporate suppliers for price-gouging during the war, the well-known $A L C O A$ opinion, written by Supreme-Court-Justice-for-a-Day Learned Hand, the prewar study of corporate size and efficiency by the prestigious Temporary National Economic Committee (TNEC) (finding that efficiency did not correlate with large-scale production), and finally, the persuasive power of the enormousiy influential book by Berle and Means, The Modern Corporation and Private Property (1932), describing the historical and economic circumstances surrounding the separation of ownership and control in large corporations and in consequence, the unaccountability of corporate management. ${ }^{20}$

In this context, the Celler-Kefauver Act can be seen as a compromise rather than an attack on bigness: Bigness was not presumptively beneficial insofar as the influential TNEC study showed that large-scale did not guarantee efficient production.

19 Act of March 21, 1938, ch. 49, 52 Stat. 111, amending the Federal Trade Commission Act, 15 U.S.C. \$§ 41-58 (1980).

20 Act of December 29, 1950, ch. 1184, 64 Stat. 1125, amending Clayton Act $\$ 7,15$ U.S.C. $\$ \S 18,21$ (1980); U.S. v. Aluminum Co. of America, 148 F.2d 416 (2d Cir. 1945); The Temporary National EcoNomic Commitee (TNEC), Relative EfFciency of LaRge, MEdIUM-Sized, and SMall Business (Monograph No. 13, 1941). 
Moreover, bigness carried with it the economic power to influence commercial and political dealings. On the other hand, corporate expansion by internal growth was a mark of commercial success. The compromise, then, entailed a distinction between internal and external expansion. Internal growth was tolerable but growth by merger was not. Acquiring economic power by merger was understood as creating the costs of bigness without its benefits, as buying it rather than earning it. Under those circumstances, the local producer and the local merchant were to be given the benefit of the doubt.

The common vision animating these five statutes was a doubled "public interest"-the Siamese twins of consumer and small producer, sometimes seen in conflict and other times seen in harmony. The bond between consumer and small producer, running through all of the statutes, was a deep faith in the middle-class ideology of individualism and an equally deep ambivalence toward large modern corporations. The ambivalence toward bigness was produced by a tension between the desire for the economic benefits of large-scale production on the one hand and on the other, a desire to free competition from domination by huge corporate bureaucracies with massive accumulations of economic power. The ambivalence, as well as the deep faith in individualism, were both economic and political, both practical and ideological.

\section{Conclusion}

The phrase "managed competition" can be understood as an historical archive of visions, as a sequence of answers to a simple question: From what tyranny do you want to free competition? The three historical examples I have presented provided three different answers in three different historical and economic contexts. To the extent that we find ourselves in parallel economic circumstances or in similar ideological dilemmas, history can bring to the surface a political unconscious, a collective memory to inform our current deliberations about managing competition. 
